\title{
FEMALE IMAM AND KHATIB The Progressive Tradition of Gender-Responsive Practices in Balingka, West Sumatera ${ }^{1}$

\author{
Busyro \\ IAIN Bukittinggi, West Sumatera - Indonesia | busyro.pro18@gmail.com
}

\begin{abstract}
Abstrak: The practice of allowing women to be the imam and khatib for Eid prayer in Balingka has become a long tradition for more than a century. The simple way of thinking, the topographic problem, and the intention to form united community have allowed this tradition to be still practiced today. In reality, such tradition has never been mentioned in the classic figh (Islamic jurisprudence). In fact, allowing women to be the imam and Khatib in Eid prayer never occurs in Islamic community from other regions. To reach the goal of silaturrabim (the bond of friendship) between the local settlers and perantau (local people who live or work in other regions) also contribute to the perseverance of this tradition. This practice serves as the intermediary between the tendencies of fanaticism of traditional Islam and the radical religious changes offered by liberal Islam. Unknowingly, this practice, which is started from the small village, and inspired from the simple way of thinking, has implemented the notion of gender equality that promoted by the group of progressive Islam.
\end{abstract}

Keywords: Female imam, female khatib, progressive Islam, gender equality.

\section{Introduction}

One of the Sunnah prayers in Islam, which is performed congregationally, is the prayer of Eid al-Fitr and al-Adha. These two

\footnotetext{
${ }^{1}$ This topic is taken from the research that the author did in Nagari Balingka, Agam Regency West Sumatera. The uniqueness of this tradition is that it allows women to be the imam and khatib in Eid prayer, which is not practiced in other regions in Indonesia. The writer would like to express his gratitude to his students, Bahrul Hamdi and Muhammad Dinil Haq, who assisted him in collecting the datas from the field and searching for the journals related to this topic.
} 
prayers are performed in the morning once a year for each Eid, in two raka'ats, and followed by the sermon (khutbah) from the khatib who has previously been appointed or selected by the community. This sunnah prayer is different from other congregational prayers, that the people who perform this prayer are required to recite takbir seven times in the first rak'at and five times in the second one. Furthermore, the supplication recited between the takbeers is also particular and is not recited in other prayers, except istisqa' prayer (prayer asking for the rain). ${ }^{2}$

In common practice, Eid prayer is led by an Imam and is then followed by the sermon from the khatib who are deemed fit to be in those two positions. Some common requirements for imam and khatib are that they are male with appropriate age and religious knowledge (faqih) and have outstanding ability in Qur'anic recitation. ${ }^{3}$ There are no other specific sex-related criteria for imam and khatib in Eid prayer found in Islamic literatures. Other sources of fiqh (Islamic jurisprudence) also never mention about the possibility of women to become the imam and khatib for Eid prayer.

However, there are many opinions from the ulemas on this kind of practice. Imam al-Shâfi'i mentioned that it is possible for the women to be the imam in congregational prayer, but it is only for female congregation. ${ }^{4}$ On the other hand, Imam Malik forbade women to be the imam in this kind of congregational prayer in any condition. From these two opinions, it seems that the ulama's agreed that women are not allowed to be the imam for men. ${ }^{5}$ It is based on Hadith narrated by Ibn Mâjah: that "women are not supposed to be the imam while the

\footnotetext{
2 Taqiy al-Dîn Abû Bakr Muhammad al-Husainî, Kifâyah al-Akhyâr (Surabaya: AlHaramain, 2005), p. 153.

${ }^{3}$ Muhammad bin Idrîs al-Shâfî̂, al-Umm (Beirut: Dâr al-Kutub al-Ilmiyah, 2001), Vol. II, p. 194.

${ }^{4}$ Abû al-Hasan 'Ali bin Muhammad bin Habîb al-Basrî al-Baghdâdî al-Mâwardî, alHâmî al-Kabîr fi Fiqh Madžhab al-Imâm al-Syâfì , (Beirut: Dâr al-Kutub al-Ilmiyah, 1999), Vol. II, p. 356; see also 'Abd al-Rahmân bin Muhammad 'Iwadh al-Jazîrî, al-Figh 'Alâ al-Madzâhib al-Arba'ah, (Beirut: Dar al-Kutub al-'Ilmiah, 2003), Vol. I, p. 372; see also Abû al-Walîd Muhammad bin Ahmad bin Muhammad bin Ahmad bin Rushd alQurtubî, Bidâyah al-Mujtahid wa Nihâyah al-Muqtashid, (Surabaya: al-Haramain, n.d.), p. 105.

5 al-Qurtubî, Bidâyah al-Mujtahid.
} 
ma'mum are men't Other fuqaba' (Islamic scholars on Islamic jurisprudence) allow women to be the imam for women on the basis of their equality in prayer.

In fact, the possibility for women to become imam can be found in many Hadiths from the Prophet Muhammad. One of the Hadith is narrated by Abû Dâwud from Ummu Waraqah that the Prophet Muhammad once visited Ummu waraqah in her house, and appointed a muaddhin (the Muslim official of a mosque who summons the faithful to prayer from a minaret five times a day), and then instructed Ummu Waraqah to be the imam for the whole members of her household.

Based on this Hadith, women are allowed to be the imam for other women. According to al-Asqalânî in the book of Bulügh al-Marâm, that Hadith happened on the condition that there are two men under the protection of Ummu Waraqah; an old man and a male slave. Up to this point, the significant problem of women becoming imam in congregational prayers may not yet be found. However, the ulemas of figh mainly concern about the congregational prayer in general, such as compulsory prayers, not on Eid prayer with its own peculiar characteristics and rituals.

As the time goes by, the method of understanding Qur'an and Hadith as the Islamic sources is developing. This development then generated the schools of Islamic jurisprudence, from the simple model to the progressive model of Islamic jurisprudence. The Islamic jurisprudence, whether the simple model or the progressive, has changed many religious traditions.

The debate on the possibility of women to be the imam is raising again as the response to the widely discussed discourse of gender. In its first development, the notion of gender, which promotes the equality between men and women, only focused on discussing about the fair treatment for both men and women in the social fields, such as education and social strata. The proponent of this gender did not discuss about the equality on nature-related traits for men and women.

The discussion on gender notion-then moved onto the possibility for women to be the leader in the given community. This issue $t$ is also the outcome of gender-responsive thought, which suggest that there are no differences between men and women in their access to the education.

${ }^{6}$ Abu Abdullah Muhammad bin Yazid al-Khuzaimi bin Majah, Sunan Ibnu Majah, (Riyadh: Maktabah al-Ma'arif, 1417 H), p. 442. 
However, the debate on gender problem continues to develop as gender activists conduct many controversial issues on religious practices, especially when it is related to ibadah (religious practice). In many years ago the Islamic community was shocked by a gender activist woman, Amina Wadud, who became the imam and khatib for Jumat (Friday) prayer in Virginia, USA. ${ }^{7}$ This practice became a controversy issue among the Islamic community, because it had no support from the Islamic literatures. According to Solikul Hadi, such gender-related innovation sometimes has led to the distortion of Quran and Sunnah. ${ }^{8}$

What Amina did was inspired by the rational model of thought, that there is no different between men and women in performing ibadah (religious practice). Quoting several verses from Quran, Heri Junaidi states that both devout men and women are promised to come to the paradise by Allah SWT. ${ }^{9}$ The discourse of gender from the West was also influenced the notion of equality between men and women in all aspects, including in the ibadah (religious practice) aspects.

Even though Amina Wadud has proposed and practiced the idea of women becoming the imam and khatib in Jum'at Prayer, the similar idea was previously proposed and practiced in Eid prayer long before in Nagari Balingka, Sub-district IV Koto, Agam Regency West Sumatera.

As previously mentioned, the practice of Eid prayer in Nagari Balingka is different from other regions in Indonesia, even in the whole Islamic community. As discussed previously, the possibility for women to be the imam in the congregational prayers is only in certain conditions and only in their own household. In addition, the Islamic view on khatib for Eid prayer is not particularly discussed by ulemas. It is probably because the activity of imam is considered the same as that of khatib.

\footnotetext{
${ }^{7}$ Charles Kurzman (ed.), Wacana Islam Liberal Pemikiran Islam Kontemporer tentang Isu-isu Global. Original Title "Liberal Islam A Sourcebook" (Jakarta: Paramadina, 2001), p. 185.

8 Solikul Hadi, "Bias Gender Dalam Konstruksi Hukum Islam di Indonesia," Jurnal Palastren, vol. 7, no. 1 (2014), p. 27.

9 Heri Junaidi and Abdul Hadi, "Gender dan Feminisme dalam Islam," Muwazah, Vol. 2, No. 2 (2010), pp. 247-248; see also M. Nur Kasim, "Perspektif Islam Tentang Gender," Jurnal Inovasi, vol 9 No. 2 (June 2012), p. 7.
} 
This study is getting more interesting because this case was came from the rural community, who are not inspired from the notion and the movement of gender or feminist activists. In their opinion, the idea of allowing women to be the imam in Eid prayer seems to be simple. So, the idea and practice of allowing women to be the imam in Balingka is one of good case for research.

Therefore, this study will attempt to expose the thought construction of Balingka community regarding this phenomenon, which will include the background, the practice, and the relationship of this Eid prayer with the ideas of progressive Islam and the study of gender.

\section{Islamic Jurisprudential Overview on Imam and Khatib for Eid Prayer}

As far as it can be found in Islamic literature on the discussion related to the imam and khatib for Eid prayer, in those positions, are not particularly mentioned. Such discussion in literatures of figh mainly concern only on the procedures, the places, the praying supplications, and the number of takbir of Eid prayer. Hence, it can be concluded that the requirements of imam and khatib for Eid prayer are similar to those of other congregational prayers.

This conclusion is based on the figh discussions on the practice of congregational prayers, that all ulemas agree on the position of imam and khatib for men. The book of al-Umm gives long explanation about congregational prayer, but it does not mention about the possibility of women to be the imam in Eid prayer. The discussion only on the problem of the integrity of the imam and khatib. Therefore, what ulema of fiqh mainly focus is only on the requirements for the imam and khatib. For example, according to Imam Maliki, the imam and khatib must be the most devout men with the best attitude and the best ability in Quranic recitation. ${ }^{10}$

According to the study on the general guidelines of congregational prayers in figh (Islamic jurisprudence), it is possible for women to be the imam as stated by Imam al-Shâfî̀. According to him, women are allowed

10 Malik ibn Anas ibn Malik ibn 'Amir al-Ashbahi al-Madini, al-Mudawwanah (Beirut: Dar al-Kutub al-'Ilmiyah, 1994), Vol. I, p. 176. 
to be the imam for other women and children. ${ }^{11}$ However, Imam Malik mentions otherwise. ${ }^{12}$ Although some ulemas agrees on the possibility of women to be the imam, they also seem to agree that women are not allowed to be the imam for men. It is based on the Hadith narrated by Ibn Majah, that women are not supposed to be the imam when the ma'mum is or are men.13 Nonetheless, there is still possibility for women to be the imam if the ma'mum is or are women.

Due to this fact, in their discussion on Eid prayer, ulemas of figh no longer focus on discussing about who will be the imam and khatib; rather, they focus on other problems related to times, procedures, and sermon requirements. Such as on the matter of praying times, it which is mentioned that Eid prayer can be started from the sunrise until the sun in three meter height and ends before the decline of the sun, similar to dhuba prayer time. ${ }^{14}$

The discussing also about the matter of khutbah; that khatib must stand if it is possible and sit between the two sermons; being clean from hadath and najeez and also covers the aurat. ${ }^{15}$ In terms of sermon requirements, khatib must begin the sermon with praising Allah, recite two shabadah, recite salawat for the Prophet, advise on the taqwa, recite Quran in one of the two sermons and pray for the Muslims in the second sermon. ${ }^{16}$

In simple term, those are some guidelines on the practice of Eid prayer according to the classic figh (Islamic jurisprudence). Despite of their wide discussions, ulemas have different views on several matters. But, they have no different views on the imam and khatib for Eid prayer, that it is only for men.

11 Abû al-Hasan 'Ali ibn Muhammad ibn Habîb al-Bashrî al-Baghdâdî al-Mâwardî, alHâwî al-Kabîr fi Fiqh Madžbab al-Imâm al-Syâfi' î, (Beirut: Dâr al-Kutub al-Ilmiyah, 1999), Vol. II, p. 356.

12 Abû al-Walîd Muhammad ibn Ahmad ibn Muhammad ibn Ahmad ibn Rusyd alQurtubî, Bidâyah al-Mujtabid wa Nihâyah al-Muqtashid (Surabaya: al-Haramain, n.d.), p. 105.

13 Abû 'Abdullâh Muhammad ibn Yazîd al-Khuzaimî ibn Mâjah, Sunan Ibn Mâjah (Riyâdh: Maktabah al-Ma'ârif, 1417 H), p. 442.

14 'Abd al-Qadîr al-Rahbâwî, Shalat Empat Mą̧hab (Jakarta: PT Intermasa, 1995), p. 357

15 Ibid., pp. 358-359.

16 Abdul Aziz Dahlan (ed.), Ensilopedi Hukum Islam (Jakarta: PT Ikhtiar Baru Van Hoeve, 1997), p. 1583. 


\section{Some Ideas of Progressive Islam}

Talking about progressive Islam is very interested, because it has the inclination toward the advancement of religious understanding. The term of progressive Islam is given to the group who promote the ideas of social evolution and do not solely stick to the old and traditional idea blindly. ${ }^{17}$

The ideas of progressive Islam face many opposition since they changed many standard practices in Islamic ritual and jurisprudence which have become long tradition in Islam. Despite many challenges, the ideas of progressive Islam are continuously spreading. Their ideas are not only related to the universal values of Islamic teaching, such as justice and freedom, but also extends to the area of Islamic law.

They also promote the idea of progressive ijhtihad that necessitates the reinterpretation to the sources (nas) of Islamic law and reframing the method on defining law in order to make the nature of Islamic law more flexible and elastic, which was promoted by the previous mujtahid long years ago, and what the previous ulema did will be more practiced in the real life. ${ }^{18}$ According to Fariz Noor, the spirit of progressive Islam is to bring up the relevancy of Islamic law with the reality in the given time and place. ${ }^{19}$

According to Omid Sofi, there are several important issues that progressive Islam must answer, such as on the concept of gender inequality, the discrimination against religious and ethnic minorities, the human rights violation, the recognition of freedom of speech, belief, and religious practice, wealth inequality, and authoritarian government. 20

Abdullah Saeed proposes six classifications of Islamic thought; traditional, puritan, political, hard-line, secular, and progressive. Progressive Islam is the understanding of contemporary Islamic thinkers who have sufficient mastery on classical Islamic thought and

\footnotetext{
${ }^{17}$ Farish A. Noor, Islam Progresif; Peluang, Tantangan dan Masa Depannya di Asia Tenggara (Yogyakarta: SAMHA, 2006), pp. 22-23.

18 Abdullah Saeed, Islamic Thought An Introduction (London and New York: Routledge, 2006), p. 140.

${ }^{19}$ Kamaruzzaman Bustamam-Ahmad, "Contemporary Islamic Thought in Indonesia and Malay World, Islam Liberal, Islam Hadhari, and Islam Progresif," Journal of Indonesian Islam, vol. 05, no. 01 (June 2011), p. 116.

20 Jasser Auda, Maqasid al-Shariah as Philosophy of Islamic Law: A System Approach (London: IIIT, 2008), pp. 177-179.
} 
attempt to reinterpret the religious understanding, through ijthibad by using the methodology from many perspectives. ${ }^{21}$

Saeed also mentions six characteristics of progressive Muslims: adopting the understanding that several dimensions of traditional Islamic law need to changes and also promoting the substantial reformation in order to adapt with the current need of Muslim today; having the tendency to support the necessity of new methodology in ijtihad to solve the contemporary issues; combining the traditional Islamic school of thought with the modern education from the West; believing that the social changes, whether in intellectual, moral, legal, economic, or technological domains must be reflected in Islamic law; abstaining themselves from participating in certain legal school of thought and theology; and emphasizing their thought in the importance of social justice, gender equality, human rights and harmonious relation between Muslims and non-Muslims.22

The above-mentioned categories are similar to the ones proposed by Tariq Ramadan. He classifies them into six groups that represent famous Muslims' perspective in $20^{\text {th }}$ and $21^{\text {st }}$ century: scholastic traditionalism, salafi literalism, salafi reformism, political literalist salafism, liberal or rational reformism, and then sufism. According to him, progressive Muslims are in the group of liberal and rational reformism. ${ }^{23}$

Contemporary Islamic epistemology, in Saeed's view, is different from the traditional one since modern Western education can be seen as the factor that inspires the proponents of contemporary Islam to achieve their desired goals. The humanistic problems and issues become apparent when Saeed mentions social justice, gender equality, human rights, and harmonious relationship between Muslims and nonMuslims. These contemporary humanistic problems cannot be understood well by using the methods and approaches from traditional

\footnotetext{
${ }^{21}$ Abdullah Saeed, Islamic Thought An Introduction (London and New York: Routledge, 2006), pp. 150-151.

22 Ibid.

${ }^{23}$ Tariq Ramadan, Western Muslims and the Future of Islam (New York: Oxford University Press, 2004), pp. 24-28: compared with Umma Farida who classifies the Islamic thought paradigms into three: Conservative Islam, Liberal Islam, and Moderate Islam. These three thinking paradigms are professed by pesantren (Islamic schools) in Indonesia. See Umma Farida, "Radikalisme, Moderatisme, dan Liberalisme Pesantren: Melacak Pemikiran dan Gerakan Keagamaan Pesantren di Era Globalisasi," Jurnal Penelitian Pendidikan Islam, vol. 10, no. 1 (February 2015), pp. 149-150.
} 
Islamic epistemology. The traditional approaches mentions is the classical method of ushul figh, classical figh, and the whole salafisticrelated thought. It is also stated by Ibn 'Asyur that the application of classical method of ushul figh must be reconsidered because of its lack of concern on humanistic values (insaniyab) and freedom (burriyab). ${ }^{24}$

The justice, kindness, and order are the universal Islamic values that become the spirit of the defined laws. Any traditional rules and legal status with no respect to justice, kindness, and order must be abandoned and must be then changed into the universal principles of Islam by using the progressive approach of ijtihad. Only through this way, Islam will be able to respond to the contemporary problems, such as human rights, gender, pluralism and the likes..$^{25}$

As previously discussed, one of the focuses in progressive Islam is the issue about gender equality, that is how to implement the divine order related to sexual and gender differences in the response to the changes in many aspects of life due to the modernity. In one side, Muslims feels obligated to conform to their Islamic tradition through divine authority and a set of figh understanding that have been set and practiced for centuries. On the other, they also encounter current phenomena which some of their aspects do not correspond to the practiced tradition. Muslims will inevitably face difficulty in uniting their perception on this matter. Some may be fanatic and strongly bound to their tradition; others fully support this modernity while some others take their position in the middle. The progressive Islam is in this last position.

\section{Gender Equality in the Thought of Progressive Islam}

Progressive Islam claims that Islamic community will not be able to bring up justice in the absence of legal guarantees for female Muslims. Gender equality becomes the benchmark of the wide concern on social justice and pluralism. According to Safi, gender issues are not only related to women, but also to men. Gender inequality do not only concern on the societal system that oppresses women, but also concern on the system demeaning the dignity of men. The scopes of gender discourse do not restricted only on the matter of

\footnotetext{
${ }^{24}$ Muhammad al-Thâhir ibn 'Âsyûr, Maqâsbid al-Syarìah al-Islâmiyyah (Yordania: Dâr alNafầis, 2001), pp. 89-111.

${ }^{25}$ M. Arfan Mu'ammar, Islam Progresif dan Ijtihad Progresif Membaca Gagasan Abdullah Saeed (Yogyakarta: IRCisoD, 2012), p. 360.
} 
bijab, but it also extends to the many fundamental issues of social construction that influence the lives of both men and women. ${ }^{26}$

Quoted from Mansoer Faqih and Musdah Mulia, Ida Rasyidah mentions that the determinative components which cause the problem of gender inequality are varied, some of which are cultural values, religious tradition, social and political structure and system. ${ }^{27}$ In this condition, progressive Islam attempt to gain recognition as the movement of Islamic feminism. they believes in the contextual particularity and diverse female identity; combines feminist discourse with female Muslim discourse on their involvement in gender issues; open the opportunity for meaningful dialog and sisterhood between Muslim women and other women from other religion, and cultural contexts. Therefore, feminisms can be seen as the contemporary response on the matter of Quranic order to bring up justice and equality.

According to Nurcholis Madjid, progressive Islam is in the neutral position in examining tradition and modernity. Hence, the principle of progressive Islamic is to reform people's understanding on their religious teachings and to practice those teachings in the given society. Meanwhile, the goal of this reformation is to make the religion more functional in responding to modern challenges. Therefore, in such construction of thought, progressive Muslims do not want to be trapped in the dichotomy of traditionalism and modernity and posit themselves as the intermediary. ${ }^{28}$

\section{Female Imam and Khatib in Balingka Nagari Balingka}

Balingka is a nagari [read; village] located in sub-district of Ampek Koto Agam Regency West Sumatera. This nagari consists of three jorong [read: small villages] which are Jorong Koto Hilalang, Jorong

\footnotetext{
${ }^{26}$ Omid Safi, Introduction, Progressive Muslims: On Justice, Gender, and Pluralim (Oxford: Oneworld, 2003), pp. 9-10.

27 Ida Rasyidah and Noersyamin Aini, "Perempuan dan Ketidakadilan: Review atas Beberapa Isu Gender Menyangkut Dunia Kerja," Literatur Review in Studia Islamika, vol. 16, no.1, (2009), p. 156.

28 Ahmad Amir Aziz, Neo-Modernisme Islam di Indonesia (Jakarta: Rineka Cipta, 1999), pp. 26-27; compared with Martin Van Bruinessen in Din Wahid, "Kembalinya Konservatisme Islam Indonesia," Book Review in Studia Islamika, vol. 21, no. 2 (2014), p. 377.
} 
Pahambatan, and Jorong Subarang Sianok. Each jorong has its own mosque with the name corresponding to the name of the jorong where it is located; The Grand Mosque of Koto Hilalang, The Grand Mosque of Pahambatan and The Grand Mosque of Subarang.

Nagari Balingka with its width \pm 2.820 is the capital of Ampek Koto sub-district located in 1000-13000 M height above the sea and surrounded by mountainous areas with many valleys. This nagari borders with the following Nagaris: to the north with Nagari Koto Gadang and Nagari Koto Panjang, to the south with sub-district of Malalak, to the east with Nagari Koto Tuo and to the west with Nagari Sungai Landia. The number of population in Balingka is 5.880 consisting of 2.886 men and 2.994 women distributed in 488 households. The dominant professions found here are merchant, farmer, and tailor (website of Nagari Balingka).

Balingka lies at the foot of Mount Singgalang with topographic conditions of hills and valleys. This community is well-known as successful perantan (local people who live and work in other places especially big cities), whether as the merchant or entrepreneur. Many famous ulemas also come from this nagari such as Sheikh Daud alRasyidi, Sheikh H. Abdul Muin, Sheikh Ibrahim Musa Parabek, dan H. Mansur Dt. Palimo Kayo (The first head of West Sumatera Council of Ulemas). Another famous public figure from this village is Bung Karni Ilyas, presenter of TV One in the show of Indonesia Lawyer Club (ILC).

With difficult topography and far locations among the jorong, Balingka community makes a genius policy regarding the practice of Eid prayer. Infrequent face-to-face interaction, whether among local settlers or perantau, has led to the introduction of separating men and women in Eid prayer, both Eid al-Fitr and Eid al-Adha. It seems that this community absorbs the positive effects of this tradition even though such practice has no basis in the classical Islamic thought. This is the interesting point of this long practiced tradition. This phenomenon will be examined from the perspective of progressive Islam in its relation to gender equality.

\section{The Background of the Idea of Female Imam and Khatib in Eid Prayer in Balingka}

Balingka belongs to regional customary law of Minangkabau, which practice the matrilineal tradition. One of distinctive 
characteristics of this tradition is deriving one's family line from the mother's side. Therefore, women has important position in Minangkabau and also own the entire inherited wealth (tanab ulayat), left by their predecessors. The reformative movement conducted by several previous ulemas, such as Sheikh Ahmad Khatib alMinangkabawi, had no effect when he tried to change the tradition of this inheritance and family line. Probably, this thing becomes one of the considerations in allowing women to be the imam and khatib for Eid prayer in this region. In 1927, to substantiate the position of Balingka women, Djami'atoenniswan established the association of Balingka women led by Rangkayo Roekajah Rasyad. ${ }^{29}$

According Naswar Datuk Penghulu Dirajo, The Head of Nagari Balingka, the separation of men and women in Eid prayer has been practiced since 1916, following the uniting of three regions in this area to be one Nagari [read; village], Balingka. ${ }^{30}$ According to Adi Sutan Pamuncak, the age of Balingka is similar to one-century period in 2016. ${ }^{31}$ Therefore, the practice of Eid prayer with women as the imam and khatib has occurred for a century.

The uniting of three jorong into one nagari leads to the expanding area of the nagari. The wide distance between the jorong has an effect on the practice of Eid prayer. ${ }^{32}$ Balingka community, well-known for their unity, eventually decide to unite the whole community of those areas, one of which is to combine all men to pray Eid in a certain mosque. Similarly, all women are also asked to pray in the certain mosque. ${ }^{33}$ Especially for women, the community also appoint women to be the imam and khatib. ${ }^{34}$

The separated praying places between men and women are aimed to make Balingka community know each other, strengthen the bond of the silaturrabim (fellowship) both local people and perantau. ${ }^{35}$ In addition

\footnotetext{
${ }^{29}$ Fauzan Ismail, "H. Idris Dt. Maruhun Kayo Tokoh Pendiri Balingka," in Majalah Balingka (Jakarta: July-August 2016), p. 44.

30 Ibid., p. 41-42; also Naswar Datuk Penghulu Dirajo, Personal Interview, Balingka, 10 August 2016.

31 Adi Sutan Pamuncak, "Satu Abad Balingka," Majalab Balingka (Jakarta: July-August 2016), p. 3.

32 Tafkir, Personal Interview, Kubang Putih, 11 August 2016.

33 Naswar Datuk Penghulu Dirajo, Personal Interview, Balingka 10 August 2016.

34 Warnita, Personal Interview, Balingka 10 August 2016.

${ }^{35}$ Naswar Datuk Penghulu Dirajo, Personal Interview, Balingka 10 August 2016.
} 
to this consideration, the topographic condition of Balingka with hills and valleys does not provide the community with the vacant field that can be used the praying place for entire people within this community. ${ }^{36}$ Therefore, it is decided to separate men from women for the same goal, to unite the people in Balingka community.

This practice of allowing women to be the imam and khatib has no clear basis from the sunnah (Prophetic tradition). However, since it was firstly conducted, local ulemas have not showed their disagreement on this practice. Some of them even support it. According to Naswar, some of the outsanding ulemas from this community are Sheikh Ibrahim Musa Parabek, Sheikh Daud Rasyidi, and Buya HMD Dt. Palimo Kayo (The head of Council of Ulemas for West Sumatera). Those ulemas do not reject the position of women to be the imam and khatib for Eid prayer. ${ }^{37}$

From the discussion above, it can be seen that the problem underlying the practice of allowing women to be the imam and khatib does not based on the gender issue. However, it stems from the factor of uniting the community and the natural factor of the absence of vacant field in Balingka that can be used for Eid prayer. Aziz Thalib describes the strong unity of Balingka community as follows: "In the far isolated doesoen (small village) from the city (more or less $10 \mathrm{Km}$ ) people will be amazed to see and to think the strong bond and unity of its people with their high spirit to bring the lucky condition for their religion". ${ }^{38}$

Basically, the practice of Eid prayer in Balingka community is not different from that of other places. It can be seen from the time, procedure, place, and sermon. What distinguish it from other places is that in this prayer they concentrated in two mosques, one mosque form men only and the other for women and children only.

As previously discussed, there are three grand mosques in Balingka. Every year, the community will alter the Eid prayer in these three mosques. If this year Men prays in the mosque A, the women will pray in the mosque $\mathrm{B}$. Alternatively, the next year men will pray in the mosque $\mathrm{B}$ and the women in the mosque $\mathrm{C}$ and so forth.

\footnotetext{
36 Warnita, Personal Interview, Balingka 10 August 2016.

${ }^{37}$ Naswar Datuk Penghulu Dirajo, Personal Interview, Balingka 10 Agustus 2016.

38 Aziz Thaib, Taman Raja (Padang: Pedoman Oemoem Taman Raya Balingka Fort De Kock, 1939), p. 10.
} 
According to Naswar, for the last few years, the imam and khatib for women are Ermawati and Taslim Rasyid. ${ }^{39}$

According to Balingka community, this tradition has long been practiced, that the people within this community can visit and get to know each other,d as well as able to pray in all mosques of Balingka. The alternately used mosques for eid prayer is aimed to from silaturrabim and unity among the people of Balingka so that they will have the similar sense of belonging to their village and hometown. ${ }^{40}$

Seen from the Balingka topography, the distance between one jorong from another is quite far. Some jorong are located in the steep foot of Mountain Singgalng and others are in the deep valley. With recent advancement, the whole jorong can be reached by the motor vehicle with the good road condition. However, the distance between one jorong for another is still far (more or less $2 \mathrm{Km}$ ). If eid prayer is performed in their own places, like in other areas, the people of Balingka will likely have the chance to get know and to visit each other.

With this practiced tradition, it actually has no relation to the privileges given to women, rather it is quite related to the unity of men. If the women are unite, the men will inevitably follow. The tradition of getting together in this village during Eid prayer will eventually affect on the unity of Balingka community in other places. It can be seen from the organizations established by Balingka community wherever they live.

\section{The Model of Progressive Islam Practice of Gender-Responsive in Eid Prayer in Balingka}

Progressive Islam, as previously mentioned, desires the changes in the standard of traditions practiced in the Islamic community. This idea stems from the differences in understanding religious texts, from the textual understanding and traditional to rational understanding. The traditional group wants to practice the teaching as it received by the first generation of Islam without any changes. Conversely, liberal rational group demands for the changes in understanding Islam due to the changes in time and place where this teaching is practiced.

Islamic Liberal rationality often brings to the conclusion to the necessity of the total re-conception of Islamic traditions that have long

\footnotetext{
${ }^{39}$ Naswar Datuk Penghulu Dirajo, Personal Interview, Balingka 10 August 2016.

40 Ibid.
} 
been practiced by Muslim community, even though these changes have torn apart the religious texts from Quran and Sunnah. The progressive Islamic thought appears to accommodate this issue.

In one hand, progressive Islam wants the perseverance of traditionalism as it is, but on the other hand it also desires the changes to adapt with the changing time. Progressive Islam can be seen as the intermediary for chaotic condition of Islamic thought. Gender justice and equality is one of the important parts of progressive Islamic thought. According to gender study, men and women are the similar creature with equal rights and responsibilities before God. There is no different among them in the terms of humanity, despite their different form and biological condition. ${ }^{41}$

Gender justice and equality that promoted in the social scopes is one of the changes which is desired by the progressive Islam. It includes giving the equal right for men and women to be a leader.

However, the struggle to change the traditional Islamic understanding about female leadership is not easy, yet it is gradually accepted by most Islamic community. Gender-related debates continue spreading due to the controversial practices carried out by gender activists known as feminists. Gender equality discussed is not only in the scope of social community, but also in the scope of ibadah mahdah. For example, Amina Wadud appointed herself to be the imam and khatib for Jum'at prayer in Virginia USA. ${ }^{42}$

The understanding, promoted and practiced by Aminah Wadud, has never been found and conducted by anyone since the coming of Islam. It will inevitably lead to the wide controversy, because it is related to ibadah mahdah. In widely practiced Islamic understanding, the rules related to ibadah is not inspired solely from logic and reason, but

${ }^{41}$ Zumrodi, "Pendidikan Sensitif Gender Dalam Islam: Telaah Paragdimatis Dalam Sejarah Intelektual Islam Indonesia," Jurnal Palastren, vol. 8, no. 2 (December 2015), p. 285.

42 According to Rusydi, the spirit of gender equality promoted by Amina Wadud is inspired from the paradigm that she calls tauhidic paradigm i.e men and women are equal before God. Tauhidic paradigm provides equal opportunity to be devout God's servant regardless of social strata, nationality, classical patriatic culture. Through this tauhidic paradigm, she finds that biological differences are not the factor defining the degree and status of humankind in Islam. In short, she wants to mention that men and women are equal before Allah see Lihat M. Rusydi, "Relasi Laki-laki dan Perempuan dalam al-Qur an menurut Amina Wadud," Miqot, vol. XXXVIII, no. 2 (July-December 2014), p. 278 and p. 291. 
from clear nash (religious texts). Therefore, the practice from Amina Wadud can be classified as liberal Islam even though it promotes gender equality.

Regarding to the practice of allowing women to be the imam and khatib for Eid prayer, it also can be seen as the promotion of gender equality with progressive theme. What the community do in Nagari, allowing women to be the imam and khatib for Eid prayer, cannot be considered the same to what Amina Wadud did, as liberal Islam. It is due to the following considerations:

First, seen from the religious textual basis, what women do in Balingka has religious basis from the Prophetic tradition, although the basis used does not explicitly mention Eid prayer. As it is narrated by Abu Dawud, the Prophet appointed Ummu Waraqah to be the imam for her own household. It is suggested from this Hadith that there is possibility for women to be the imam for her family, and the family mentioned here means her female family and children. It is also supported by the opinion from Imam al-Shâfi'î and Abu Hanifah. Different from Amina Wadud, the practice that she did contradicts to the Hadith, which explicitly forbids women to be the imam for men.

Second, the congregations (makmum) of Eid prayer led by female imam and khatib in Balingka are women and children, while men pray in the different mosque. Unlike Amina Wadud, she became the imam and khatib for male congregations too.

The practice conducted by Balingka community in allowing women to be the imam and khatib for Eid prayer essentially has abandoned the traditional ways (read: conservative) that are commonly practiced by Islamic community. Regardless the motivations and the desired goals, Balingka community has done changes (modernity), which indirectly applied the gender justice and equality promoted by progressive Islam. Even though they are not inspired from the concepts that developed by proponents of gender and feminism as well as progressive Islamic understanding, they have taken the accommodated position among the contradictory Islamic understandings between conservatively traditional Islam and liberal Islam.

\section{Conclusion}

From the above-mentioned discussion, it can be concluded that the practice of allowing women to be the imam and khatib for Eid 
prayer is based on the goal to unite Balingka community; both from this nagari and from rantan (other places), and is caused by the unavailability of vacant area to perform Eid prayer due to the topographic conditions of this area with hills and valleys. The practice of Eid prayer in Balingka is not different from that of other places. It is only that they separate men from women in Eid prayer.

The practice of Eid prayer in Balingka has indirectly applied to progressive Islamic thought, related to gender justice and equality and has taken the accommodated position between traditional Islam and liberal Islam.]

\section{References}

\section{Books and Articles}

al-Husainî, Taqîy al-Dîn Abû Bakr Muhammad. Kifâyah al-Akhyâr. Surabaya: Al-Haramain, 2005.

al-Jazînî, 'Abd al-Rahmân ibn Muhammad 'Iwadh. al-Figh 'Alâ alMadzâabib al-Arba'ah. Vol. II. Beirut: Dâr al-Kutub al-'Ilmiah, 2003.

al-Madînî, Mâlik ibn Anas ibn Mâlik ibn 'Amîr al-Ashbahî. alMudawnanah. Vol. I. Beirut: Dâr al-Kutub al-'Ilmiyah, 1995.

al-Mâwardî, Abû al-Hasan 'Ali ibn Muhammad ibn Habîb al-Bashrî alBaghdâdî. al-Hâmî al-Kabîr fi Fiqh Madz̧bab al-Imâm al-Syâfìi. Vol. II. Beirut: Dâr al-Kutub al-Ilmiyah, 1999.

al-Qurthubî, Abû al-Walîd Muhammad ibn Ahmad ibn Muhammad ibn Ahmad ibn Rusyd. Bidâyah al-Mujtabid wa Nihâyah alMuqtashid. Surabaya: al-Haramain, n.d.

al-Rahbawî, Abd al-Qadîr. Shalat Empat Maz̧hab. Cetakan kedua. Jakarta: PT Intermasa, 1995.

al-Syâfî̀̂, Muhammad ibn Idrîs. al-Umm. Vol. II. Beirut: Dâr al-Kutub al-Ilmiyah, 2001.

Auda, Jasser. Maqasid al-Shariah as Philosophy of Islamic Law: A System Approach. London: IIIT, 2008.

Aziz, Ahmad Amir. Neo-Modernisme Islam di Indonesia. Jakarta: Rineka Cipta, 1999.

Bustamam- Ahmad, Kamaruzzaman. "Contemporary Islamic Thought 
in Indonesia and Malay World, Islam Liberal, Islam Hadhari, and Islam Progresif." Journal of Indonesian Islam. vol. 05, no. 01 June (2011): pp. 91-129

Dahlan, Abdul Aziz (ed.). Ensilopedi Hukum Islam. Jakarta: PT Ikhtiar Baru Van Hoeve, 1997.

Farida, Umma. "Radikalisme, Moderatisme, dan Liberalisme Pesantren: Melacak Pemikiran dan Gerakan Keagamaan Pesantren di Era Globalisasi." Jurnal Penelitian Pendidikan Islam, vol. 10, no. 1, Februari (2015): pp. 145-163

Hadi, Solikul. "Bias Gender Dalam Konstruksi Hukum Islam di Indonesia." Jurnal Palastren. vol.7, no.1 (2014): pp. 25-46

Hamidah, "Gerakan Tahrirul Mar`ah dan Feminisme (Studi Terhadap Kesetaraan Gender Dalam Islam." Wardab: No. 22/ Th. XXII/Juni (2011): pp. 1-8

Ibn 'Âsyûr, Muhammad al-Thâhir. Maqâshid al-Syari'ah al-Islâmiyyah. Yordania: Dâr al-Nafầ is, 2001

ibn Mâjah, Abû Abdullah Muhammad ibn Yazîd al-Khuzaimî. Sunan Ibn Mâjah. Riyâdh: Maktabah al-Ma'ârif, 1417 H.

IDSS. "Progressive Islam and The State in Contemporary Muslim Societies." Seminar paper held in Marina Mandarin Singapore, 2006

Junaidi, Heri and Abdul Hadi. "Gender dan Feminisme dalam Islam." MUWÂZAH, vol. 2, no. 2 (December 2010): pp. 245-256

Kasim, Nur M. "Perspektif Islam Tentang Gender." Jurnal Inovasi, vol. 9, No. 2 (June 2012): pp. 1-8

Khariri, "Kesetaraan Gender Dalam Perspektif Islam Reinterpretasi Fiqh Wanita." Yin Yang, vol. 4, No. 1 (Jan-Jun 2009): pp. 27-40

Kurzman, Charles (ed.). Wacana Islam Liberal Pemikiran Islam Kontemporer tentang Isu-isu Global. Original title "Liberal Islam A Sourcebook." Jakarta: Paramadina, 2001.

Mu'ammar, M. Arfan, Islam Progresif dan Ijtibad Progresif Membaca Gagasan Abdullab Saeed. Yogyakarta: IRCisoD, 2012

Noor, Farish A. Islam Progresif; Peluang, Tantangan dan Masa Depannya di Asia Tenggara. Yogyakarta: SAMHA, 2006.

Pamuncak, Adi St, Majalah Balingka. July-August 2016. 
Ramadan, Tariq, Western Muslims and the Future of Islam. New York: Oxford University Press, 2004.

Rasyidah, Ida and Noersyamin Aini. "Perempuan dan Ketidakadilan: Review atas Beberapa Isu Gender Menyangkut Dunia Kerja." Literatur Review in Studia Islamika. vol. 16, no.1, (2009): pp. 151-186

Rusydi, M. "Relasi Laki-laki dan Perempuan Dalam al-Qur`an Menurut Amina Wadud." MIQOT, vol. XXXVIII, no. 2 (Juli-Desember 2014): pp. 276-294

Saeed, Abdullah, Islamic Thought An Introduction. London and New York: Routledge, 2006

Safi, Omid, Introduction, Progressive Muslims: On Justice, Gender, and Pluralim. Oxford: Oneworld, 2003

-------. "Modernism: Islamic Modernism." Lindsay Jones et.al,. Encyclopedia of Religion. Farmington Hills: McMillan, 2005

--------. "Chalenges and Opportunities for the Progressive Muslim in North America." Muslim Public Affairs Journal, 2006

Thaib, Aziz. Taman Raja. Padang: Pedoman Oemoem Taman Raya Balingka Fort De Kock, 1939

Wahid, Din, "Kembalinya Konservatisme Islam Indonesia." Book Review in Studia Islamika. Vol. 21, no. 2 (2014): pp. 375-390

Zumrodi, "Pendidikan Sensitif Gender dalam Islam: Telaah Paragdimatis dalam Sejarah Intelektual Islam Indonesia." Jurnal Palastren. vol. 8, no. 2 (Desember 2015): pp. 271-292.

\section{Interviews}

Interview with Warnita, Balingka, 10 Augustus 2016

Interview with, Tafkir, Kubang Putih, 11 Agustus 2016

Interview with Naswar Dt. Dirajo, Balingka, 10 Agustus 2016 
Busyro

Volume 11 , Number O2, DeCEMBER 2017 